\title{
CREATIVITY AS A FACTOR SUPPORTING DEVELOPMENT OF SMART SPECIALISATION AT THE STAGE OF UNIVERSITY EDUCATION
}

\author{
Joanna MACHNIK-SŁOMKA \\ Silesian University of Technology, Faculty of Organisation and Management; joanna.machnik-slomka@polsl.pl
}

\begin{abstract}
The article deals with significance of creativity considered as a significant mechanism supporting development of smart specialisations. Creativity is most frequently analysed in the context of innovation and perceived as a more effective way of implementing innovative processes. This increases the need for knowledge and creative thinking skills. In that respect, universities ought to play a key role. The article highlights interrelations between development of smart specialisations and the need to integrate creativity into university curricula.
\end{abstract}

Keywords: creativity, smart specialisations, universities.

\section{Introduction}

Development of smart specialisations depends on various factors and mechanisms, in particular those affecting innovative activity and development of employees' creative attitudes. Therefore, this article focuses on the construct of creativity treated as one of key mechanisms of smart specialisation development.

In accordance with modern trends related to intelligent development, the economy, various organisations, institutions, and businesses need educated professionals with creative thinking and problem solving knowledge and skills. The knowledge and the skills facilitate the process of selection and development of smart specialisations. In this regard, universities play an important role.

The role of the university education sector is primarily to develop and social human capital, knowledge infrastructure, knowledge and skills in accordance with needs, and commercialisation of research results (Guide..., 2012). To optimally use the potential of a specific region, the university education system ought to take into consideration the market demand for specialised personnel within the framework of identified smart specialisations. This is an important element of building and acquiring human capital for the innovation 
ecosystem that generates new ideas for innovative solutions which bring benefits to the European economy and society.

The aim of the article is to discuss the nature and importance of creativity to development of smart specialisations at the stage of university education. The article also presents theoretical assumptions of the smart specialisation concept and the role of universities in their development. Moreover, the article presents selected educational programmes and projects regarding creativity, implemented on the national and the regional level, based on an exemplary university.

\section{The essence of smart specialisations}

The concept of smart specialisation is oriented at achieving and maintaining competitive advantage of EU countries and regions in the global economy owing to the concentration of knowledge and focusing it on a limited number of priority actions (Guide..., 2012). According to the concept, regions and countries that combine innovation with their unique strengths and capabilities of the economy based on the infrastructure and knowledge base as well as the industry structure have a greater chance of success (Guide..., 2012). The concept of smart specialisations is the outcome of the work of the K4G: Knowledge for Growth Expert Group appointed in 2005. Assumptions regarding the regional specialisation idea, co-authored by, inter alia, D.P. Foray (David, Foray, and Hall, 2007), were presented in 2008 in the working documents of the Group as well as in a report containing recommendations regarding the functioning of the European Research Area (The role..., 2009). Creators of smart specialisation name four key principles on which the concept is based (quadruple ' $\mathrm{C}$ '): tough choices and critical mass, competitive advantage, connectivity and clusters, and collaborative leadership (Foray, Goddard, and Beldarrain, 2012). The concept was primarily popularised with the Communication from the European Commission titled Europe 2020: A strategy for smart, sustainable and inclusive growth (KOM 2010 (2020), 2010). Smart specialisation remains closely related to one of the three main priorities of the Europe $2020-$ Smart development based on knowledge and innovation strategy. It is also a pillar of one of the seven flagship initiatives known under the name of 'Innovation Union', falling within the framework of the Europe 2020 strategy.

The concept of smart specialisation is an important implementation element of the innovation policy. In practical terms, of crucial importance was the Guide to Research and Innovation Strategies for Smart Specialisations (RIS3), published in May 2012 and developed with the use of a smart specialisation platform. The Guide contained detailed instructions for regions and Member States with respect to methods of development and implementation of research and innovation strategies for smart specialisations. Development of the 'Research and 
Innovation Strategies for Smart Specialisations (RIS 3) is designed to allow the use of EU structural funds more efficiently and to increase the synergy between different EU, national and regional policies as well as public and private (http://ec.europa.eu/...) investments. RIS 3 is a key part of the proposed reform of the EU cohesion policy that supports thematic concentration and strengthens strategic programming and effectiveness (http://ec.europa.eu/...). These strategies are supposed to encourage all partners to integrate within a common vision and to develop a creative social capital within the community.

Smart specialisation means identification of unique characteristics and assets of each country and region, highlighting of the competitive advantage of each region, and concentrating regional partners and resources around an accomplishment-oriented vision of their future (http://ec.europa.eu/...). It also means strengthening of regional innovation systems, maximising of knowledge transfers, and dissemination of innovation benefits throughout the entire regional economy (http://ec.europa.eu/...).

The very concept of smart specialisation is based on various underlying theories (see Table 1).

Table 1.

Theories to which the concept of smart specialisation refers

\begin{tabular}{|c|c|}
\hline Theories & $\begin{array}{l}\text { Theory description } \\
\end{array}$ \\
\hline Neo-factor theories & $\begin{array}{l}\text { Apart from work and capital, the theories classify human capital and natural } \\
\text { resources of the country as production factors. }\end{array}$ \\
\hline Nanotechnological theories & $\begin{array}{l}\text { They stress the importance of technological developments and innovation that } \\
\text { affect intensification of exports from a specific national economy. }\end{array}$ \\
\hline Technological gap theory & $\begin{array}{l}\text { The theory lists technologically innovative countries that are capable of } \\
\text { creating new products and solutions, and imitating countries that build their } \\
\text { competitive position based on less expensive production factors. }\end{array}$ \\
\hline Staple theory by H. Innes & $\begin{array}{l}\text { According to Innes, regional development is driven by the creation of gradual } \\
\text { specialisation in the production of products that are considered to be the } \\
\text { strongest in external markets in terms of competitiveness. Specialisation of } \\
\text { production results in a reduction of transaction costs, primarily as a result of } \\
\text { improved production processes and resulting product quality. }\end{array}$ \\
\hline $\begin{array}{l}\text { Flexible Production theory } \\
\text { by Piore and Sabel }\end{array}$ & $\begin{array}{l}\text { The concept assumes that development based on small and medium-sized } \\
\text { enterprises, freely changing the nature and direction of production to adjust to } \\
\text { prevailing market conditions, technological developments and consumer } \\
\text { requirements makes it possible to define specialisation that may contribute to } \\
\text { identification of a market niche in the global market. }\end{array}$ \\
\hline $\begin{array}{l}\text { Absolute Advantage theory } \\
\text { by A. Smith }\end{array}$ & $\begin{array}{l}\text { According to the absolute advantage theory, selection of specialisation on the } \\
\text { national level is determined by absolute differences in the costs of production } \\
\text { of a specific product. }\end{array}$ \\
\hline $\begin{array}{l}\text { Heckscher-Ohlin theorem } \\
\text { by E. Hechscher and B. } \\
\text { Ohlin }\end{array}$ & $\begin{array}{l}\text { According to the theory, selection of specialisation is determined by the } \\
\text { difference in the costs and prices of production factors generation that are } \\
\text { a function of rarity or abundance of those factors in individual countries. }\end{array}$ \\
\hline $\begin{array}{l}\text { Industrial Districts concept } \\
\text { by A. Marshall }\end{array}$ & $\begin{array}{l}\text { An industrial district is defined as a spatially separate area in which } \\
\text { specialised industrial plants are located. Industrial districts form stable local } \\
\text { communities with a well-developed service infrastructure supporting } \\
\text { specialised regional production. }\end{array}$ \\
\hline
\end{tabular}




\begin{tabular}{|l|l|}
\hline $\begin{array}{l}\text { Competitive Advantage } \\
\text { theory by M.E. Porter }\end{array}$ & $\begin{array}{l}\text { Porter's concept, having elements that are common with Marshall's industrial } \\
\text { district theory, emphasises the importance of geographical proximity } \\
\text { (agglomeration, spatial concentration) and of establishment of industry } \\
\text { clusters within which there arise cooperative interrelations. The concept is } \\
\text { based on the location paradox, meaning that in the contemporary economy the } \\
\text { production process is located locally, although goods produced are sold } \\
\text { globally. }\end{array}$ \\
\hline $\begin{array}{l}\text { Growth Poles concept by } \\
\text { F. Perroux }\end{array}$ & $\begin{array}{l}\text { According to the concept, the growth poles identified have the strongest } \\
\text { market position and are characterised by dynamic growth of economic } \\
\text { activites as well as strong cooperative interdependencies. Not only do they } \\
\text { drive economic growth but also constitute a potential capable of subordinating } \\
\text { and making dependent business entities which are weaker than them. The } \\
\text { Growth Poles theory is also related to the most developed regions. }\end{array}$ \\
\hline
\end{tabular}

Note. Original study based on: "Strategia inteligentnej specjalizacji w kontekście wybranych regionów Polski” by E. Romanowska, A. Firgolska, and J. Hrudeń. Copyright 2014, p. 55-78.

Consequently, the concept of smart specialisation is not completely new. It is but an improvement to the existing structural fund planning methodology. It is based on regional experiences in the area of supporting innovative strategies and on the leading economic thought on the part of leading international institutions, for instance the World Bank, or the OECD (http://ec.europa.eu/...).

\section{Creativity as a mechanism supporting intelligent specialisations}

A key premise of the concept of smart specialisation is the application of the entrepreneurial exploration of new domains of specialization (Guide..., 2012) and learning processes. Thus, there is a need to identify factors required to implement the process and to create an effective innovation system that fosters diffusion of various types of innovation. Due to its importance within innovative processes, creativity plays an important role in that respect. This has been noted by, inter alia, Sexton and Browman-Upton (Sexton, and Browman-Upton, 1991). Creativity turns out to be a critical competence in the functioning and entrepreneurial development of modern organisations as well as in the implementation of innovative undertakings and projects. Consequently, creativity is becoming more and more crucial as the right brain material that contributes to the generation of the highest level of growth (Knop, Szczepaniak, and Olko, 2014, p. 246). Wu and others emphasise particular importance of creativity in the implementation of new undertakings which are the basis for generating new ideas that initiate the process of entrepreneurial $(\mathrm{Wu}, \mathrm{McMullen}$, Neubert, and Yi, 2008) and innovative activity.

To a large extent, smart specialisation development possibilities result from the use of employees' research and development capacity. This, in turn, depends on employees' creativity and innovativeness. As J. Brzóska emphasises, the level of growth of organisation's innovation depends on pro-innovative activity, formation of support for employees' creative 
attitudes, their competences and ability to cooperate (Brzóska, 2014, p. 38-48). It is considered that creativity is a mixture of, on the one hand, interaction of intellectual competences, creative talents and personal characteristics, and, on the other hand, a broadly interpreted socio-cultural and economic environment, and the environment within the organisation - in the sense of organisational climate (Bednorz, 2014, p. 13). Creative attitude helps solve organisational problems, motivates and encourages employees to implement innovative solutions, and fosters better teamwork (Machnik-Słomka, 2015, p. 216-228).

Creativity is an important development mechanism of organisations and undertakings, in particular those of innovative nature, as it establishes a new outlook on the development of modern economy which, as it is more and more frequently emphasised, is subject to transformation from knowledge-based economy to creative economy (Fanea-Ivanovici, 2013, p. 65-70). Elements of both economies can be a driving force for economic and social development, developing based on human knowledge and creativity, meaning that they can contribute to smart growth based on innovation and knowledge. In this approach, it is important to capture new and creative forms of knowledge creation. The arising new paradigm of economic development is based on the assumption that creativity, knowledge and availability of information are an important driving force for economic growth which supports development in the contemporary, globalised world.

Creativity is an important, interdisciplinary subject matter of studies, interesting from both the scientific and the economic practice perspective. In management studies, researchers more and more frequently consider creativity to be an important strategic element which may constitute an important source of competitive advantage formation (e.g. Dyduch, 2013; Bratnicka, 2010; Shalley, Zhou, and Oldham, 2004; Woodman, Sawyer, and Griffin, 1993, p. 293-321), which result in the accomplishment of high efficiency (Weinzimmer, Michel, and Franczak, 2011, p. 179-192). Creativity is most frequently analysed in the context of innovation, and perceived as a more efficient way of conducting business activity, inclusive of implementation of innovative processes. Thus, it may affect selection and development of smart specialisations. It is primarily related to generation of new, useful ideas pertaining to various processes and procedures applied within an organisation. Thus, it is of primary importance to innovation formation mechanisms. According to T. Amabile, creativity is treated as a trigger for innovation, and its occurrence is a function of existence of professional knowledge, task-oriented motivation and creative skills (Amabile, 1988). It may result in new ideas and concepts, original solutions and associations as well as interrelations between existing ideas and concepts, new interrelations between elements and their combination in an unprecedented manner, original responses, thoughts, or conclusions differing from contemporary standards (Matusiak, 2011). Therefore, it is important both at the stage of selection and at the stage of implementation of smart specialisation. 
Creativity falls within the scope of the innovation theory which, in turn, falls within the scope of management sciences. Development of the innovation theory indicates continuous evolution of those phenomena, in particular in the context of globalisation developments and processes, with an ever increasing importance of knowledge, creativity and innovation. Today, these concepts are the most important keywords that are raised in both business practice and science throughout the world. Thus, they affect contemporary challenges related to smart growth. The nature and the way in which innovation is perceived have changed over the years. Not only importance of technological, i.e. product and process innovations, but also of organisational, marketing, social and ecological innovations which are of particular significance, given the priorities and the objectives of the Europe 2020 strategy, is stressed. The source literature emphasises that at present innovation results from involvement of a greater number of stakeholders than in the past; it results from the merging of a greater number of areas of knowledge which is developed within the framework of more diversified mechanisms and environments, where stronger than ever emphasis is put on, inter alia, personnel's autonomy, inciting creativity and mutual trust, communication and leadership (Kozłowski, 2013, p. 23).

In terms of smart specialisations, the construct of technology creativity that is a combination of organisational creativity and technology development is becoming particularly important (Kordel, and Machnik-Słomka, 2015, p. 163-178). Current literature covering technology creativity is most fragmentary and inconsistent. Technology creativity has been defined in the literature by several researchers, and it has been related to technological thinking and technological activity (Hyunjin Kwon, and Changyol Ryu). Technology creativity is defined as means with which people can apply knowledge in a better and more expedite manner, and thus improve the quality of life, in particular in the situation in which knowledge plays an ever greater role (Yu-Chu Yeh, and Jing-Jui Wu, 2006, p. 213227). Thus, what distinguishes the work of technology from the overall area of creativity is the primary focus on technological thinking, technological activity and technological development. Technology creativity may, consequently, play a significant role in the implementation of one of the five assumptions of the 'National/Regional Innovation Strategies for Smart Specialisation' related to the support of technological and practical innovation. Technology creativity is a unique example of managers and employee teams' creative behaviours in which creatively developed technological innovations become the primary driving force of formation and development of contemporary organisations, and of creation of market values (Machnik-Słomka, 2015, p. 216-228).

Creativity and creative processes may thus contribute to greater efficiency of the processes of entrepreneurial discovery and learning for smart specialisations. 


\section{The role of universities in the development of smart specialisations}

Universities ought to play a key role both in the process of selection and development of smart specialisations in cooperation with other stakeholders within the regional innovation system based on, inter alia, the triple (Bojar, and Bojar, 2009, p. 77-89), or the quadruple helix model (covering: the economic, the scientific and the public sector, the media, and users), concepts of the knowledge triangle (including: education, research and innovation), or by means of cooperation within networks and clusters. With respect to those ideas, universities serve a critical function, especially in terms of generating knowledge and using it to create innovative solutions in cooperation with other research centres and enterprises. Given the dominant 'market orientation', the role of users, or clients, is becoming a more and more important element of innovative processes.

Universities can contribute to regional innovation systems for smart specialisations through a series of mechanisms and instruments involving (Guide..., 2012):

- stimulation of the entrepreneurial spirit, innovation and creativity in their employees and students;

- offering advice and services to the economic sector, SMEs in particular;

- provision of experts working on identification and development of smart specialisation strategies in regions;

- participation in programmes promoting training and jobs for the best graduates with innovative companies;

- operation of academic entrepreneurship incubators as well as science and technology parks;

- active participation in operations of innovative clusters and networks;

- implementation of educational programmes and training addressed at various target groups in accordance with market demand;

- promotion of innovative solutions, also in smart specialisation areas;

- implementation of research projects within the framework of various research teams and consortia involving domestic and foreign partners;

- commercialisation of research results.

To achieve success in the field of smart growth strategy, it is important to convince all stakeholders that this is 'a collective social undertaking' based on the assumption that by working together they can accomplish more than by working separately (Guide..., 2012). Such cooperation is based on trust built on partners' reliability as well as observance and pursue of moral values (Stachowicz, and Stachowicz-Stanusch, 2011, p. 7-35). Description of the capacity-building processes and mechanisms as well as incentives for cooperation between universities and regional partners has been shown in a guide entitled 'Connecting 
universities to regional growth'. Among those mechanisms and processes, the following are listed (Guide..., 2012):

- establishment of a regional partnership for higher education in order to better understand the situation in the region and to overcome barriers;

- implementation of mechanisms with which universities and companies in the region can cooperate on the development of relevant curricula and carry out educational activities in an innovative way, providing graduates with competences needed in the region and with interdisciplinary skills, inclusive of the entrepreneurial and creative attitude;

- development of a map of a higher education system in the region that contains the following information: university entitlement to award degrees, research activity and potential cooperation with regional partners;

- evaluation of university cooperation with the public and the private sector in the region with a view to bringing about a situation in which universities are important stakeholders;

- selection, design and evaluation of interventions reinforcing university cooperation with other stakeholders in the region.

Thus, when designing and implementing educational programmes, universities ought to cooperate with external partners, companies in particular, so that graduates have relevant skills and competences which are consistent with market demands for smart specialisations. Due to the impact of innovative solutions on the broadly defined social dimension, the need to incorporate this dimension in university curricula, in particular technological university curricula (Kaźmierczak, 2014, p. 949-955), is stressed more and more frequently.

\section{Creativity in terms of developing smart specialisations within the framework of university curricula}

In the aspect of smart specialisations, there is a growing demand for creative thinking skills, ability to create new knowledge and to implement innovative solutions in practice. Consequently, curricula ought to be aligned with those needs and expectations, they ought to develop students' ability to effectively work in team, to manage team work, and to creatively solve problems in practice with the application of innovative creative thinking methods and techniques. These methods increase the efficiency of generating valuable ideas and problem solving by employees. Among these methods, one might highlight, for instance, brainstorming, mind maps, synectics, analogy method, system and algorithm methods like TRIZ (the Theory of Inventive Problem Solving) developed by Altshuller, or lateral thinking (developed by de Bono E.) (de Bono, 1970). 
Curricula covering creativity for smart specialisations ought to be addressed at various groups:

- university employees - primarily with a view to their acquisition of knowledge and skills required to teach with the application of techniques and methods of creativity, and to apply them to research processes and innovative processes;

- students - so that they acquire competencies desired in the labour market, inter alia, with respect to idea generation and problem solving;

- entrepreneurs - by providing them with access to new knowledge and competences which are of use in their professional work and which may facilitate processes of creative generation of ideas, team work, etc.;

- primary and secondary school students - so that they acquire and develop independent thinking and creative problem solving skills.

In Poland, more and more programmes and projects are being implemented by universities in cooperation with relevant partners, related to creativity and its inclusion in educational programs, for instance the 'Academic Centres for Creativity' programme. It was a programme implemented by the Ministry of Science and Higher Educations, within the framework of which universities and schools carried out research into new teaching methods and techniques (http://www.nauka.gov.pl/...). Its assumptions included cooperation and development of relationships, opportunity to share academic teachers' knowledge, opportunity for students to use university laboratories, carrying out of classes to verify new educational methods in various scientific disciplines which might then be implemented and included in curricula (http://www.nauka.gov.pl/...). Most of those projects were designed to stimulate students' independent work, to develop their independent thinking and creative problem solving skills, and to increase their motivation to study. They were dominated by workshop methods which involved a greater number of students than traditional teaching methods. In that respect, other programmes initiated by the Ministry of Science and Higher Education, and involving, inter alia, development of model teacher training programmes, were also helpful. Examples of such programmes include the 'Development of model teacher training programmes' carried out within the framework of Action 3.1 Competences in higher education. Such programmes are supposed to allow for, inter alia, innovative teaching methods (learning-by-doing, design thinking), application of digital tools, development of social competences and competences regarding educational problem solving.

Examples of universities carrying out projects in that respect include the Silesian University of Technology which, among other things, carries out training courses for its lecturers within the framework of the 'Academic Teacher's Innovative Didactics' (https://www.polsl.pl/Wydzialy/RK...) project. The project is designed to provide participants with knowledge and skills regarding possible application of innovative teaching methods in higher education, knowledge regarding the use of heuristic methods, and ability to carry out classes with the application of student-activating methods. Another project carried out by the 
Silesian University of Technology is the 'Silesian Human Resources for Innovative Entrepreneurship' project carried out within the framework of Action 11.3 RPO WSL (http://www.polsl.pl/Wydzialy/ROZ/roz2/...). It is aimed at increasing the level of professional competences desired in the regional (Silesian) labour market. Within the framework of the project, there are carried out training sessions designed for students of Silesian universities of technology and economics, and all persons who have graduated from them. The Silesian University of Technology also carries out a project called 'Creativity without barriers - University's third mission', whose leader is the Faculty of Organisation and Management of the Silesian University of Technology, working in cooperation with the City of Rybnik and the City of Zabrze (https://www.polsl.pl/Wydzialy/ROZ/Strony/...). The project is co-financed by the European Union within the framework of the European Social Fund with funds from the 'Copernicus Path 2.0' programme, as part of development of the University's offer regarding implementation of its third mission as a forum for social activity (Action 3.1 Competences in higher education, Axis III Higher education for economy and development, Operational Programme Knowledge Education Development 2014-2020). The project is aimed at secondary school students from the cities of Rybnik and Zabrze. Within the framework of the project, training courses are carried out in four thematic blocks. One of them concerns the carrying out of a workshop covering development of communication skills, critical and creative thinking, and problem-solving.

As the foregoing examples of projects carried out by the Silesian University of Technology show, they are carried out in cooperation with equal regional partners and addressed at different target groups. In addition, different faculties of the Silesian University of Technology carry out classes covering creativity and idea generation techniques. Implementation of those educational programmes and projects contributes to development of knowledge and competences regarding, inter alia, creativity, which may contribute to increased opportunities for the implementation of the regional strategies for smart specialisations. Also, the Silesian University of Technology has - since the very beginning been actively involved in processes related to the formation and implementation of the Regional Innovation Strategy, working in cooperation with the Office of the Marshal of the Silesian Province and other regional partners.

\section{Summary}

With respect to smart specialisation strategy implementation instruments, one ought to highlight importance of promoting creativity. Given that smart specialisation is of crucial importance to effectiveness of research into and investments in innovation, creativity may play a significant role. Many researchers emphasise that creativity is an important strategic 
element which contributes to greater efficiency. Thus, it may be perceived as a more efficient way of implementation of smart specialisation related projects.

The process of formation and development of smart specialisations depends on participation and involvement of various entities, inter alia, universities which ought to play a significant role in the alignment of curricula and development of science for smart specialisations. In order to develop smart specialisations, it is crucial to provide knowledge of creativity and to develop skills regarding the use of creative techniques which may facilitate processes aimed at creative idea generation and their development in innovative processes. Thus, university curricula ought to respond to social, economic and civilisational challenges. Science and higher education ought to support changes and developments in the environment by adjusting to the rapidly changing environment and contemporary challenges, that being smart growth based on knowledge and innovations.

The article contributes to further deliberations and research regarding relationships between creativity and development of smart specialisations.

\section{Bibliography}

1. Amabile, T.M. (1988). A Model of Creativity and Innovation in Organizations. Research and Organizational Behavior', Vol. 10.

2. Bednorz, K. (2014). Klimat organizacyjny sprzyjający twórczości. Studia Oeconomica Posnaniensia, Vol. 2, no. 10(271).

3. Bojar, E., and Bojar, M. (2009). The triple helix in clusters - a metropolis shaping factor. Romanian Journal of Regional Science, Vol. 3(2).

4. Bratnicka, K. (2010). Kultura organizacyjna i twórczość w przedsiębiorczych organizacjach - model koncepcyjny. Przegląd Organizacji.

5. de Bono, E. (1970). Lateral Thinking. Harmondsworth: Penguin.

6. Brzóska, J. (2014). Inteligentne specjalizacje regionu jako szansa wzrostu innowacyjności przedsiębiorstwa. Studia Ekonomiczne, no. 183, University of Economics in Katowice.

7. David, P., Foray, D.P., and Hall, B. (2007). Smart Specialisation - the concept. Knowledge Economists Policy Brief, no. 9.

8. Dyduch, W.: Twórcza strategia organizacji. Publishing House of the University of Economics in Katowice.

9. Fanea-Ivanovici, M. (2013). Urban Revitalisation in the Creative Economy and the Development of the Creative Society. Theoretical and Applied Economics, Vol. 10(587).

10. Foray, D., Goddard, J., Beldarrain, X.G. et al. (2012). Guide to Research and Innovation Strategies for Smart Specialisations (RIS 3), European Commission. 
11. Hyunjin Kwon, and Changyol Ryu. Model of Technological Creativity Based on the Perceptions of Technology-Related Experts. Daejeon Technical High School, Chungnam National University, Korea. Retrieved from www.aichi-edu.ac.jp/intro/files/seika05_2.

12. Kaźmierczak, J. (2014). Technology Assessment: Educational Challenge. In R. Knosala (eds.), Komputerowo Zintegrowane Zarzadzanie. Opole: Oficyna Wydawnicza Polskiego Towarzystwa Zarządzania Produkcją.

13. Knop, L., Szczepaniak, M., and Olko, S. (2014). Innowacje społeczne w kreatywnej Europie w perspektywie Strategii Europa 2020. Zeszyty Naukowe Politechniki Ślaskiej 'Organizacja i Zarzadzanie', no. 73.

14. Kordel, P., and Machnik-Słomka, J. (2015). Przedsiębiorczość oraz twórczość technologiczna jako mechanizmy rozwojowe organizacji wysokich technologii. Zeszyty Naukowe Politechniki Śląskiej 'Organizacja i Zarządzanie', no. 80.

15. Kozłowski, J. (2013). Wiedza na potrzeby polityki naukowej i innowacyjnej - badania naukowe, analizy, scoreboard. In P. Zadura-Lichota (eds.), Świt innowacyjnego społeczeństwa. Trendy na najbliższe lata. Warsaw: PARP.

16. Machnik-Słomka, J. (2015). Zachowania twórcze w organizacjach wysokich technologii. Zeszyty Naukowe Politechniki Częstochowskiej, 'Zarzadzanie', no. 19.

17. Matusiak, K.B. (2011). Od przedsiębiorczości technologicznej do opartej na wiedzy (kreatywnej) - innowacyjna przedsiębiorczość ery postindustrialnej. 'Zeszyty Naukowe Uniwersytetu Szczecińskiego'.

18. Guide to Research and Innovation Strategies for Smart Specialisations (RIS 3) (2012). Luxembourg: Publications Office of the European Union.

19. Romanowska, E., Firgolska, A., Hrudeń, J. (2014). Strategia inteligentnej specjalizacji w kontekście wybranych regionów Polski. Przedsiębiorstwo we współczesnej gospodarceteoria i praktyka, no. 2.

20. Sexton, D.L., and Browman-Upton, N.B. (1991). Entrepreneurship: Creativity and growth. New York: MacMillan.

21. Shalley, C.E., Zhou, J. and Oldham, G.R. (2004). The effects of personal and contextual characteristics on creativity: where should we go from here? Journal of Management, Vol. 30(6).

22. Stachowicz, J., and Stachowicz-Stanusch, A. (2011). Klastry - współczesną i przyszłościową formą organizacji potęgującej wiedzę i wartości. Organizacja i Zarządzanie, no. 4.

23. UNCTAD (2008). Creative Economy Report. The United Nations Conference on Trade and Development.

24. Weinzimmer, L.G., Michel, E.J., and Franczak, J.L. (2011). Creativity and Firm-Level Performance: The Mediating Effects of Action Orientation. Journal of Managerial Issues, Vol. 21(1).

25. Woodman, R., Sawyer, J., and Griffin, R. (1993). Toward a Theory of Organizational Creativity. Academy of Management Review, Vol. 18. 
26. Wu, C., McMullen, J.S., Neubert, M.J., and Yi X. (2008). The influence of leader regulatory focus on employee creativity. Journal of Business Venturing.

27. Yu-Chu Yeh, and Jing-Jui Wu (2006). The cognitive processes of pupils technological creativity. Creativity Research Journal, Vol. 18, no. 2.

28. The Role of Community Research Policy in the Knowledge-based Economy (2009). Retrieved from http://ec.europa.eu/research/era/pdf/community_research_policy_role.pdf.

29. KOM 2010 (2020). Retrieved from http://ec.europa.eu/eu2020/pdf. Available online 03.03.2010.

30. http://ec.europa.eu/regional_policy/sources/docgener/informat/2014/smart_specialisation_ pl, European Commission.

31. http://www.nauka.gov.pl/aktualnosci-ministerstwo/akademickie-centra-kreatywnoscipierwszepodsumowanie-programu.html.

32. https://www.polsl.pl/Wydzialy/RK/idna/Strony/O_Projekcie.aspx.

33. http://www.polsl.pl/Wydzialy/ROZ/roz2/Strony/slaskiekadry.aspx.

34. https://www.polsl.pl/Wydzialy/ROZ/Strony/Kreatywnoscbezbarier.aspx. 